\title{
Rural Areas Management on the Basis of Actual Data of the State Immovable Property Cadastre of Russia
}

\author{
Irina Vladimirovna Shmidt ${ }^{1}$, Aksana Anatolyevna Tsarenko ${ }^{1} \&$ Vasily Voldemarovich Neyfeld ${ }^{1}$ \\ ${ }^{1}$ The Saratov State Agrarian University, Russia \\ Correspondence: Irina Vladimirovna Shmidt, The Saratov State Agrarian University, Russia. E-mail: \\ iv-schmidt@yandex.ru
}

Received: February 13, 2015

Accepted: February 23, $2015 \quad$ Online Published: April 7, 2015

doi:10.5539/mas.v9n5p279

URL: http://dx.doi.org/10.5539/mas.v9n5p279

\begin{abstract}
The article is devoted to the effective use of actual data of the immovable property cadastre in rural areas management in Russia considering the Saratov region example. The study is based on the analysis of various definitions of the concept "rural areas management". It examines the questions of acquisition of cadastral data on agricultural land giving an example of a farm enterprise, and brings out some deficiencies of cadastral information registered in the State Immovable Property Cadastre of Russia. Moreover, the importance and role of the use of land-cadastral data is revealed in the article alongside with the formulation of proposals for dealing with some issues in this area with reference to an example of a farm enterprise.
\end{abstract}

Keywords: rural areas management, cadastral information, land lot, cadastral data, rural areas, land tenure

\section{Introduction}

At present, rural areas management is one of the most urgent issues.

Russia has experienced dramatic changes in land ownership and land tenure since the dissolution of the Soviet Union at the end of 1991: agricultural land has been largely privatized, individual landowners now have legal rights to most agricultural land in the country, and previous prohibitions on buying and selling of land have been removed by recent laws. The necessary pre-conditions for the development of agricultural land markets have been met and we are beginning to witness transactions that involve individual landowners, and not only the state (Lerman, Shagaida, 2007).

Today, there are many problems connected with this sphere, including ineffective recording of natural resources of a municipal district, lack of actual data of immovable property cadastres, ambiguity of the relationship of real estate ownership rights. Such problems revealed themselves when the land rights were delimitated alongside with the appearance of land lots of agricultural lands. Another factor here was amalgamation of two systems: the system of agricultural land registering and the system of registering buildings, constructions, premises and units of constructions in progress.

The purpose of the study is to examine and analyze rural areas management on the basis of actual data of the immovable property cadastre. To achieve this objective it is necessary to meet the challenges of innovative development of rural areas.

Realization of the tasks set depends on a number of factors. Thus, it is reasonable, first of all, to reconsider management approach to rural areas and agro-industrial complex in general. Besides, it is necessary to pay more attention to actual cadastral data and the received land-cadastral information, to its reliability and timeliness, and also to keep qualitative record of rational land use. The main task of the immovable property cadastre is collecting information about the land, which will help, first of all, to plan, control and manage farming of the territory. Generation of the immovable property cadastre data is provided by topographic-geodesic, aerospace, cartographic and land surveying work; soil and geo-botanical examinations and investigation; land monitoring work; quantitative and qualitative land record; making a cadastral report on a particular land lot and making land-cadastral cards and the land lot identification documents.

In general, the goal of the study is to reveal the problems in application of the present cadastral data in rural areas management, and to supplement actual and reliable data to the immovable property cadastre. 


\section{Literary Review}

\subsection{State Immovable Property Cadastre as the Basis for the Territory Management}

The State Immovable Property Cadastre and cadastral registration of real property units include: planning and conducting the cadastral territory zoning; verification and acceptance of materials on real estate unit formation; formation of cadastral reports; keeping correction sheets and plans; recording real estate units and giving them cadastral numbers of the territory; keeping land-cadastral archive; providing information of the state cadastral record to persons concerned. The state immovable property cadastre has not only fiscal function in any state, but it also serves as an information resource helpful in making management decisions. Thus, at present in Russia there is a territory development conception, which requires territory development prognostication and attracting investments to the region.

A unit of cadastral record and cadastral data keeping is a land lot, allotted within limited space and assigned to the subjects of land relationship according to the established order.

A land lot as interpreted by the cadastre is a natural resource, a territory and a real estate unit, which is considered as material value, having functions of a means and subject of labour. Thereby it is a spatial basis necessary for the human's life and the production process. But since the land lot is, first of all, a natural resource, especially if this land lot is a piece of agricultural land, it possesses qualitative characteristics, which can be inexhaustible only in case of correct and efficient use.

\subsection{Notion of "Rural Lands"}

Before considering the question under discussion it is necessary to give the definition of the term "rural areas". This notion has been defined by many scientists, including economists, geographers, political scientists, sociologists, land surveyors and others.

There is no definite definition of the term "rural areas". Thus modern researchers, for example, define rural areas an interconnection between the economic and social systems and the natural environment. Researches of such kind are conducted by modern economists, sociologists, as well as land surveyors, cadastre workers and many other scientists. Economists and sociologists study rural areas management from the point of view of development of the agricultural sector and other types of production, demographic structure and quality of people's life. Land surveyors accentuate land managing works and organization of the territory in managing rural areas.

Thus, Kovalenko E.G. subdivides in his work "all rural areas can be divided into two economic types, which determine the life-style of the population: areas with competitive economy (where effective enterprise function) and areas with uncompetitive economy, from which people (especially young people) go to cities" (Kovalenko, 2012).

Nikulina E.V. suggests understanding the notion "rural areas" as an inhabited territory outside large cities, which includes all natural conditions and resources that can be found there, local population and different elements of the main production funds and culture (Nikulina, 2010).

The author of another work (Zaytseva, 2013) justly differentiates the term "rural areas" from the term "countryside": Rural areas, like any other objects, take a particular place in the geographic space. The connection of the place to the territory is displayed in the fact that any place is the definite point on the territory. That is why usage of the term "countryside" synonymously to the term "rural area" is justified with regard to its basic level, represented by a farmstead, village or settlement. But any unity of such places should be denoted by the term "rural areas" and not by the term "countryside".

Quite a complete definition of "rural areas management" is given by the author Kookueva V.V.: Rural areas management system should include a number of interconnected processes, which are aimed at the increase of the efficiency of management of social and economic development of the area; at the arrangement of conditions for self-development and steady development of a territorial entity, management subjects and population" (Kookueva, 2013).

In his works Volkov S.N. pays great attention to deterioration of the qualitative condition of agricultural lands in the Russian Federation, which influences the development of rural areas. So, the author believes that "the main way out of the existing situation is to create a proper system of managing land resources in the Russian Federation and to introduce a package of land survey works. The order of land management, the structure, kinds and content of land survey works must proceed from the necessity to form a model of long-term development of the economy, based on the effective use of the land and property complex of the country; as well as the necessity to increase effectiveness of the state regulation in the sphere of the land and other property market, efficiency of protection, 
regional usage and sustained reproduction of the land resources; and the necessity to considerably increase the profit from the usage of the lands that are part of the state and municipal property" (Volkov, 2013).

Moreover, the authors of another work point out a very important issue connected with the development of border territories. One of them is the Saratov Region of the Russian Federation which borders on Kazakhstan: "Peripheral border territories of the Russian state are being denuded because of depersonalization in the land use. It is connected with deterioration of the economic situation in remote regions, unemployment and with demographic reasons (outflow of population, high death rate, etc.)" (Volkov, Kossinsky, 2013).

Settlements, according to the authors (Zhelyaskov, Ponosov, 2007), play a particular role in rural areas management. They believe that "social and economic potential of regions is mainly formed by the development level of settlements and by their infrastructure. That is why their territories are considered to be primary subjects of assessment". One can but agree with this opinion, but we should not diminish the importance of adjacent agricultural lands, which sometimes serve almost the main place of labour of the population of these settlements.

We suggest considering the question of rural areas management, first of all, from the point of view of the word "area" itself, which is interpreted as some land, having its boundaries, and consequently its area and other quantitative and qualitative characteristics, which should be recorded in the system of the immovable property cadastre. Besides, we would like to consider the principal part of rural areas, that is agricultural lands, which function as the main source of food production, and also as the place of labour application of the majority of the population.

\section{Method}

\subsection{Rural Areas Management in the Saratov Region of the Russian Federation}

IT is necessary to note that rural areas in the Saratov region are mainly presented by agricultural lands, and also by rural settlements. According to the Russian State Register's data, subdivision of the lands into categories shows predominance of agricultural lands in the structure of the land funds of the Saratov region. They cover $84.8 \%$, and forest lands cover $5.4 \%$ (Investment Strategy of the Saratov Region until 2020). So the question of rural areas management is important and urgent for the Saratov region of the Russian Federation, for these areas are responsible for food safety of the region, its economic development and welfare of the population.

Hence, we shall consider a range of problems, that are solved in the sphere of rural areas management on the basis of the actual data of the immovable property cadastre, taking an agricultural enterprise -farm - as an example (Figure 1). This agricultural enterprise is typical in its size (land area) and form of property, which reflects the state of this sector all around the Saratov region.

Figure 1 shows the plan (scheme) of the agricultural enterprise, which is included into the cadastre database. Mostly it represents the information about X, Y coordinates and about the owner of the land lot, its cadastral number and cadastral value. But it does not reveal the essence and the fact that the lot is referred to fertile agricultural lands (Tsarenko, Schmidt, 2013).

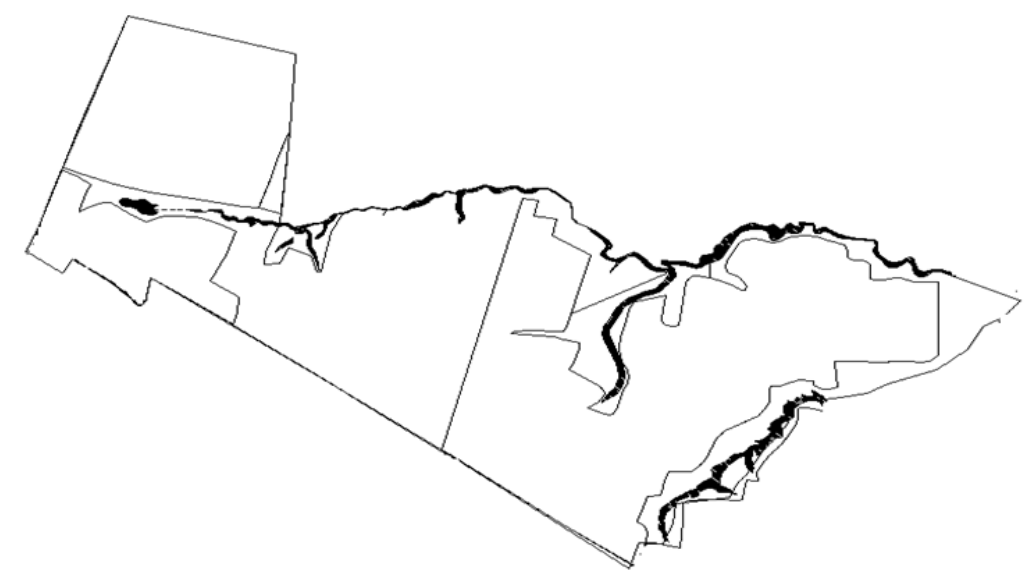

Figure 1. The scheme of the peasant farm boundary (Official site of the Russian State Register)

For effective agricultural areas management it is necessary to have the analysis based on usage and additions to the cadastral data. Peasant farm $\mathrm{N}$ was established as a result of the kolkhoz reorganization. The enterprise if 
formed from land shares (Tsarenko, Schmidt, 2013).

Now the peasant farm cultivates 1,656 ha of lands. The farm extends its arable land at the expense of rented land shares, it also buys new equipment. The owners of land shares, who have concluded lease contracts with the peasant farm, receive their profit in physical terms, for example getting forage. At present about 90 people work at the enterprise. The farm specializes in several spheres. Its principal area is plant growing. They produce crops and oil-bearing plants. Besides cattle-breeding is developing (pigstry). Crop capacity is characterized by considerable fluctuation from year to year. Such fluctuations are explained by the changes in climatic conditions, as well as by lack of the main crop rotation, fertilizing system and also by field infestation. Acreage planted of the farm is equal to $85.3 \%$ of its territory, $1.2 \%$ is covered by ravines, situated along the banks of the Sukhoy Irguiz river. Because of this the territories round them are used as pastures, which favours a more effective usage of the lands near ravines. Pastures cover $13.2 \%$ of the lands of the peasant farm "N" (Figure 2).

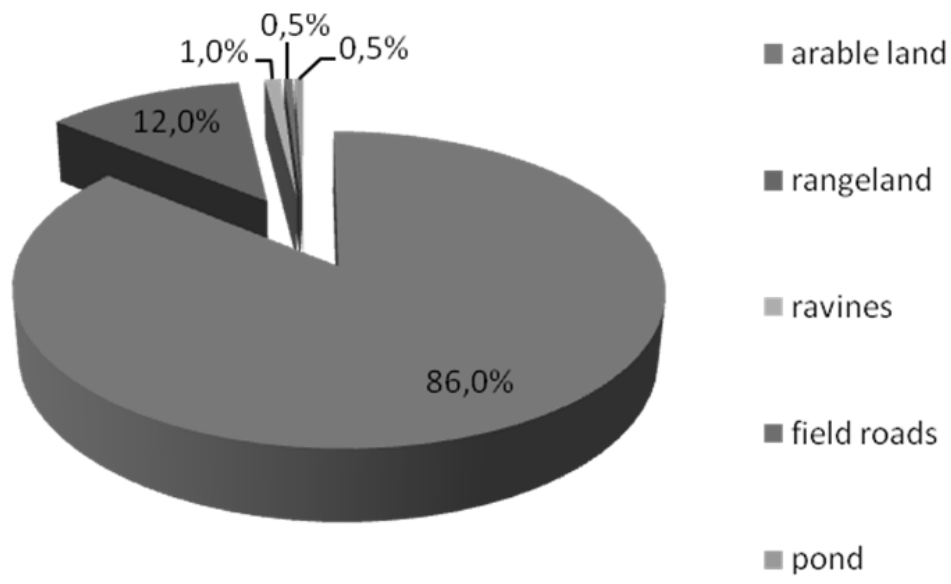

Figure 2. Structure of the peasant farm land

\subsection{Cadastral Data of Rural Areas}

Present economic situation in Russia under conditions of sanctions demands making long-term forecasts of the development of agricultural enterprises for their consolidation and for successful development of deep analysis of their activity. Effective planning and regulation of the activity of an agricultural enterprise and projection of its development are impossible without effective management of land resources of land tenure (Tsarenko, Schmidt, 2013).

Agricultural land lots require rational use of the land and ensuring steady increase of its fertility. However, characteristics of the qualitative condition of lands are not taken into consideration in the immovable property cadastre, which, on the state level, is characterized mainly by a fiscal function.

The influence of the ecological situation, of rational usage and protection of agricultural landscapes is considered by the authors of the following work (Vejre, Vesterager et al., 2015): "Management of ecological entities in agricultural landscapes is often challenged by a complex ownership structure governed by a cadastral system dictated by agricultural interests and historical land use practices. The cadastral division is suspected to obstruct the deliverance of ecosystem services (ES) from the landscape".

Agricultural lands should be thoroughly recorded from the point of view of quantitative and qualitative registering on the basis of the immovable property cadastre, which is supposed to be followed by regular land monitoring.

Moreover, actual data on the fertile land layer of agricultural lots kept in the state immovable property cadastre can be found necessary for justification of placement and specialization of agricultural industry in particular zones and economic regions, and also for introduction of scientifically substantiated agricultural and livestock farming systems.

The present system of determination of an agricultural land lot as a land share on the territory consists in making a land surveying project that will later be recorded in the cadastre. The institution of land shares itself appeared 
as a result of the land reform in Russia in the $90 \mathrm{~s}$ of the $20^{\text {th }}$ century. If we consider the requirements for the preparation of a land surveying project, we shall see that "a land lot or land lots allotted according to the project as land shares are regarded as virtual, beyond their connection with the surrounding agricultural area and its organization" (Volkov, 2013).

The State immovable property cadastre contains the following information about unique characteristics of an immovable property unit: 1) type of the immovable property unit (a land lot, building, a construction, a premise, a unit of construction in progress); 2) the cadastral number and the date when the cadastral number was added to the state immovable property cadastre; 3 ) the description of the locality of the unit's boundaries in case if this immovable property unit is a land lot; 4) the description of the location of the immovable property unit on the land lot in case if this unit is a building, a construction or a unit of construction in progress; 5) the cadastral number of the building or the construction in which the premise is situated, the number of the floor, on which this premise is situated (if there is a number of storeys), the description of the location of this premise within the storey or within the building or construction, or within the corresponding part of the building or construction in case if the unit of the immovable property is a premise; 6) area, measured with regard to the requirements set by the Federal law in case if the immovable property unit is a land lot, a building or a premise (Bevzuk, Birukova et. al., 2013).

Thus, for example, the authors of the following article (Peerbocus, Jomier, 2004) believe, and we cannot but agree with them, that "A cadastral database may be described as part of a corporate Geographic Information System (GIS), which stores spatially defined cadastral and related information in a database such as the extent, value, ownership and many other land information within a district. Lots of land may change over time. However, users may need to have access to historical cadastral information, such as the owner of a lot 1 year back or the reason for the split of a lot. Current cadastral databases are static; i.e., they represent a snapshot of the modeled administrative area".

\section{Research Results and Discussions}

Analysing activity of an agricultural enterprise it is important not to forget to raise its investment attractiveness and also to actively develop collaboration with other agricultural enterprises of the district. Particular role is given to the development of the mechanism which is aimed at the raise of investment attractiveness of agricultural enterprises on the basis of cadastral data, which will allow making management decisions connected with land resources use: the choice of food crops, creation of crop rotations, appliance of farming systems, creation and organization of forest belts, etc.

Many scientists work at creation of a complete land-cadastral database, which will especially include information on agricultural land. For example, the author of a monograph Scalaban V.D., having analysed the establishment of the Russian cadastral system, makes one of the conclusions in his work, saying that "land cadastre and land monitoring play an essential role, since absolutely all economic units are situated on land, all their activities, in the last analysis, are actually equal to the usage of land, of natural resources,..." (Skalaban, 2009).

The authors of the book Zavialov A and Markvart E. regard a land lot as a special object of law. But apart from the legal side, they also point out the value of a land lot: "being part of the Earth crust, it is eternal and inconsumable. Areas of all land lots are limited by the size of the country's territory, hence their amount is limited, and the amount of valuable land lots, suitable for positive use, is limited to a greater degree. That means that the greater population upsurge is, the more valuable they are going to be" (Zavialov, Markvart, 2011).

Another scientist, the author of a monograph, Germanov A.V., also considers land from the point of view of law of property. Still he stresses the idea about an exceptional character of a land lot as "the basis of life and activity" (Germanov, 2011).

We cannot but agree with the opinions mentioned above; nevertheless, it would be reasonable, while considering agricultural land, to speak about the priority of its exceptional quality - fertile layer. In connection with this idea, as a result of our reasoning, we propose some additional cadastral information about an agricultural land lot, which should include: technical data - cadastral area, cadastral number, address (location); economic data cadastral valuation, market valuation, land tax; legal data - form of property, type of title (charge), authorized use; ecological data - type of land, qualitative characteristics (depth of the humus layer, reserves of humus, quality score). This information is included into the cadastre, but we propose to add some ecological factors, including qualitative characteristics of a land lot (Schmidt, 2010).

Another important piece of information on an agricultural land lot is the type of land on this lot, for example, 
arable land, pastures, hayfield, etc. Since the cadastral system does not include information on the type of land, it makes possible an irrational use of fertile land in real life, when, for example, grazing is organized on the arable land.

Thereby, the state immovable quality cadastre with its present dataset on a land lot indicates the fact, that the cadastre is only a list of immovable property units, and it does not completely answer its purpose of a system, aimed at recording land quantity and quality. The cadastre cannot fully serve as the basis for the process of land controlling and protection and for monitoring procedures for lack of reliable data on qualitative condition of agricultural lands. On the other hand, the owners of agricultural land lots, having no information about the land quality, are not interested in preserving and improving its fertility.

For effective rural areas management and in order to raise investment attractiveness, it is necessary to define the structure and types of agricultural land; to generalize the cadastral data that is already known; to analyse the present condition of the fertile layer and with regard to cadastral data single out the principal tendencies of investments into its restoration; to work out recommendations for effective land resources management.

Meeting the claimed challenges answers to the purpose of the Investment Strategy of the Saratov region until 2020 (Investment Strategy of the Saratov Region until 2020), which reveals the main factor preventing the development of the agricultural industry - exhaustion of humus (which negatively influences agrophysical, physical and chemical properties and biological activity of soil, deteriorates its water-air, thermal and alimental condition, and also worsens the ability of soil to resist such negative phenomena as acidulation and salinization).

For the purpose of improving and completing cadastral data on agricultural land lots with actual and reliable information about qualitative condition of lands and, first of all, about land fertility, we suggest introducing a three-dimensional model of the cadastral recording of agricultural land. Relief model of an agricultural land lot should be created by means of a geodetic survey reflecting three coordinates XYZ, and also by means of examination and representation of the soil fertility of a land lot. Figure 3 shows a model of such a land lot.

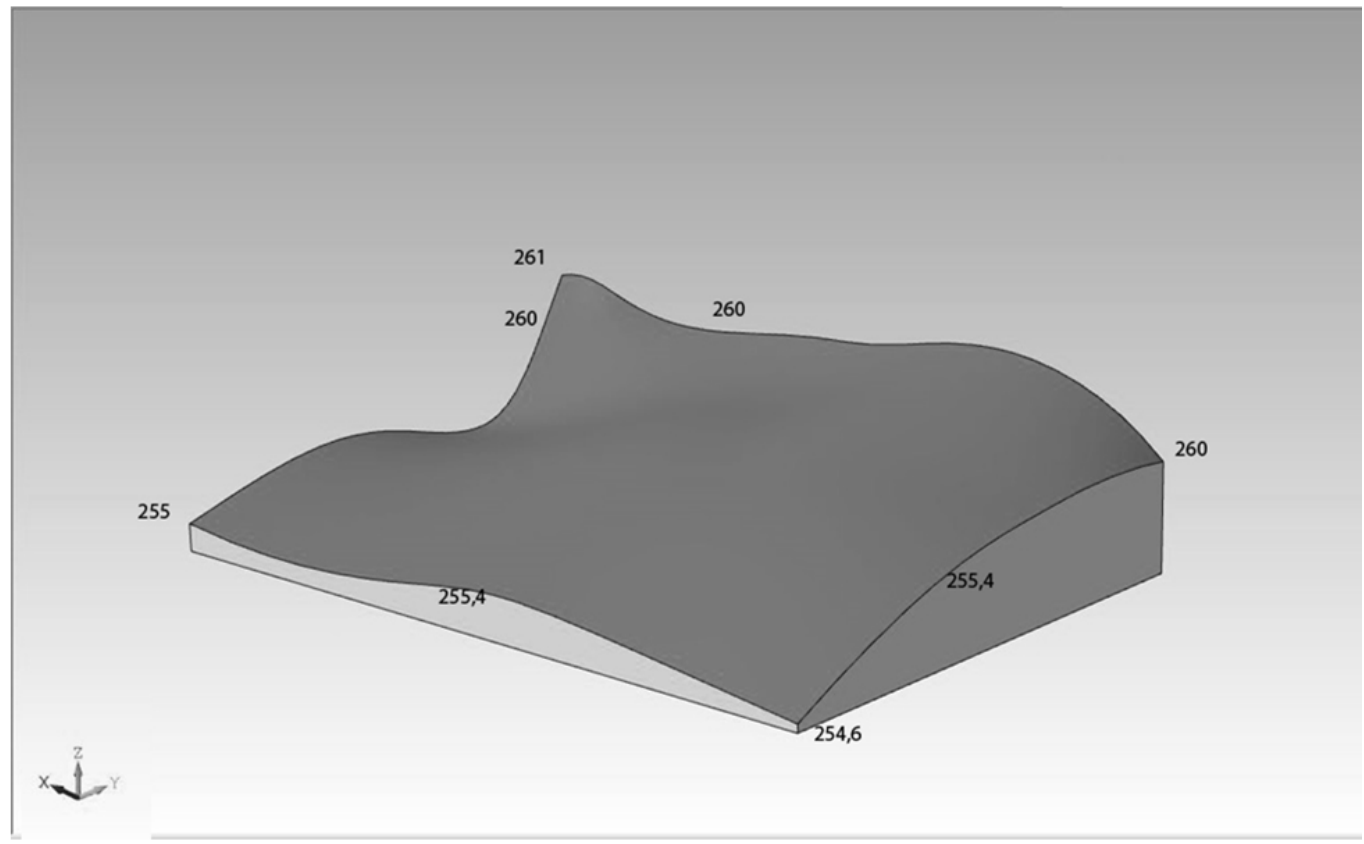

Figure 3. Three-dimensional model of a land lot

Besides, if there is a considerable variability of heights within the boundaries of a land lot, its area, represented on the plan and actually cultivated, changes greatly. Thus, comparing the area of a land lot presented in a surveying plan, which is equal to $316,000 \mathrm{sq} \mathrm{m}$, to the area presented in a three-dimensional model, which is equal to $334,573 \mathrm{sq} \mathrm{m}$, we can observe the difference equal to $18,573 \mathrm{sq} \mathrm{m}$. At that the difference in heights on the land lot is equal to $5-5.5 \mathrm{~m}$. To some extent it should also be reflected in the cadastral data, because this information may directly influence the cadastral cost of a land lot.

The studies on spatial representation of the land surface were also analysed by the authors (Mottet, Ladet et al., 2006) who have revealed the importance of recording the changes of the earth surface in the course of time: "The 
respective roles of bio-physical factors (slope and elevation) and farm socio-economic factors (farmland spatial pattern, land-tenure system) on land-use change at parcel level have also been investigated. The impact of slope and elevation on land-use type appears overall to have been greater in 2003 than in 1950. However, these factors impact differently according to the types of landscape unit: they are not determining factors in the units remote from the village, but they do have an important role in the units close to the village. The distances of the parcels from the farmstead and their access facilities appear to be the two major farm-related factors in the local context. These results confirm the important role of land-management units' spatial arrangement in land-use dynamics and landscape change, as has already been found in other regions. They are seen as a valuable addition to studies aimed at supporting sustainable management of traditional mountain landscapes for multifunctional purposes".

Creation of three-dimensional models is possible due to geo-informational systems, which allow implementing a land lot representation by taking the space above the lot and under it into account. In other words, it means representation of a fertile layer, which is an integral part of agricultural land. Besides, use of geo-informational systems allows monitoring the usage of a land lot during a long time-span. This will make control of land use and land protection possible.

\section{Conclusion}

Summing up, it is necessary to point out that rural areas management implies establishing the boundaries of all land tenures and also ordering the process of parcellation lots as land shares. Moreover, it includes improvement of the immovable property cadastral system by adding actual data due to the creation of three-dimensional models of agricultural lands. Besides, it will be necessary to elaborate in future the system of a three-dimensional cadastre of immovable property on agricultural lands, which will necessarily include information about the fertile layer. This will serve as a principal database for effective rural areas management and regular land monitoring.

\section{References}

Ally, P., \& Geneviève, J. (2004). The management of the cadastral evolution using documented cadastral plans. Computers, Environment and Urban Systems, 28(5), 487-509.

Anne, M., Sylvie, L., Nathalie, C., \& Annick, G. (2007). Agricultural land-use change and its drivers in mountain landscapes: A case study in the Pyrenees. Agriculture, Ecosystems \& Environment, 114(2-4), 296-310.

Comments to Federal Law of 24 of July, 2007 №221-FZ "On the State Immovable Property Cadastre" (paragraph-by-paragraph). E. A. Bevzuk, T. A. Birukova, A. N. Vasilyev, A. V. Galyaeva, N. P. Sanakoyeva, S. A. Shishelova, A. A. Tsarenko, I. V. Schmidt. Electronic textual data, Saratov, I.P.R. Media, 2013. 246 p. Retrieved from http:// www.iprbookshop.ru.19235

Germanov, A. V. (2011). Land lot in the system of property rights (p144). Moscow: Statut.

Investment Strategy of the Saratov Region until 2020. Official site "Investment portal of the Saratov region". Retrieved January 17, 2015, from http://mininvest.saratov.gov.ru

Kookueva, V. V. (2013). Problem of rural areas management in Russia. "Economics and Modern Management: Theory and Practice": materials of the international virtual participation scientific conference (14 of August, 2013) Novosibirsk, "SibAK" publishing house, 216.

Kovalenko, E. G. (2012). Mechanisms of sustainable development of rural areas of the region. Modern Problems of Science and Education, 2. Retrieved January 16, 2015, from http:// www.science-education.ru.102-5823

Lerman, Zvi. (2007). Natalya Shagaida Land policies and agricultural land markets in Russia. Land Use Policy, 24(1), 14-23.

Nikulina, E. V. (2010). Formation and assessment of the financial potential of sustainable development of rural areas economics. Vestnik VGU. Series: Economics and management, 2, 123.

Official site of the Russian State Register. Retrieved from http:// www.rosreestr.ru

Schmidt, I. V. (2010). Creation of a dimensional model of an agricultural land lot. Natural and Technical Sciences, 4, 201-203.

Skalaban, V. D. (2009). Agroecological data of the land cadastre in the strategy of Russia's sustainable development. Moscow, Academic project; Alma Mater, 255 p.

Tsarenko, A. A. (2013). Cdastral information usage when solving the problems of land resources management. A. A. Tsarenko, I. V. Schmidt. Modern Problems of Land Management, Land Cadasttre, Land resources Protection: materials of the international scientific conference (27 of November, 2013, Blagoveshchensk), 
Blagoveshchensk, publishing house of DalGAU, 242 p. ill., Pages 117-124.11

Tsarenko, A. A. (2014). Range of tasks, solved in the sphere of rural areas management on the basis of actual data of the immovable property cadastre. Natural and Technical Sciences, 2, 139-142. Moscow, "Sputnic +" publishing house.

Vejre, H., Vesterager, J. P., Andersen, P. S., Olafsson, J. A. S., \& Brandt, T. (2015). Dalgaard Does cadastral division of area-based ecosystem services obstruct comprehensive management? Ecological Modelling, 295, 176-187.

Volkov S. N. (2013). Improvement of land resources management in rural areas of the Russian Federation. Innovative way to a new development stage of agricultural sector: materials of the international scientific conference dedicated to the 100 anniversary of Professor M. A. Gendelman. Kazakh agrotechnical university named after S. Seydullina. Astana, Pages 32-41.

Volkov, S. N. (2013). Conception of land resources and agricultural areas management in the Russian Federation. Land Management, Cadastre and Land Monitoring, 10, 6-9.

Zavyalovm, A. A. (2011). Land relationships in the system of local self-government (p256). Moscow: Statut.

Zaytseva, O. O. (2013). Rural areas as a management subject: Notion, functions, typology. Fundamental Researches, 6(2), 416-420.

Zhelyaskov, A. L. (2007). Assessment of the socio-economic capability of rural areas when forming a settlement system. Economics of Agricultural and Reprocessing Enterprises, 6, 50-52.

\section{Copyrights}

Copyright for this article is retained by the author(s), with first publication rights granted to the journal.

This is an open-access article distributed under the terms and conditions of the Creative Commons Attribution license (http://creativecommons.org/licenses/by/3.0/). 